\title{
Body Mass Index as a Parameter of Running Speed
}

\author{
Indri Seta Septadina ${ }^{1 \#}$, Tri Suciati ${ }^{1}$ Ha Sakinah $\mathrm{Se}^{2}$ \\ ${ }^{1}$ Departement of Anatomy, Faculty of Medicine, Universitas Sriwijaya, Palembang, Indonesia \\ ${ }^{2}$ Medical Student, Faculty of Medicine, Universitas Sriwijaya, Palembang, Indonesia \\ \#Correspondence Author : indrisetaseptadina@fkunsri.ac.id \\ Received : March 19th 2019 \\ Accepted : May 9 $^{\text {th }} 2019$
}

\begin{abstract}
\section{Introduction}

Speed is determined by several factors such as anatomical and physiological factors. Body Mass Index (BMI) is one of an indicator from anthropometric measurement that is relevant to distinguish the capacity and performance of athletes.
\end{abstract}

\section{Objective}

The aim of this study is to investigate the correlation between BMI and running speed.

\section{Methods}

It was an observational research with cross-sectional design of 35 students of Athlete High School in Palembang. students. The primary data was taken from anthropometric measurements (stature meters, weight scales, meters) and assessment of 50 meters running speed tests. Data analysis was executed by using Pearson or Spearman correlation test in SPSS. The BMI of subjects varied from 17.05 to 27.12 with mean 21.48.

\section{Results}

The running speed of subjects varied from 5.67 to $8.17 \mathrm{~m} / \mathrm{s}$, with an average of $6.78 \mathrm{~m} / \mathrm{s}$. The bivariate analysis showed that there was a weak negative correlation between BMI and running speed $(r=-0160)$.

\section{Conclusion}

There was a weak negative correlation between BMI and running speed $(r=-0160)$. A negative correlation means that the greater BMI then the less time it takes to run at a distance of 50 meters, in other words, the better performance of athletes.

Keywords: Body Mass Index, Running Speed, Athletes 


\section{Introduction}

Sprint is a race conducted with a maximum running speed along the distance that must be taken, up to 400 meters $^{1}$. Sprints are a number of the most prestigious among others as they often competed in various official championship events both on a national scale, regional and international. Running is the chief of all sports movement is a combination of basic movement pattern human life ${ }^{1}$.

The main key to be an athlete to run a short distance (sprint) is speed. Speed is the ability of a person to be able to move from one place to another in the shortest possible time. This speed is locomotor and movements are cyclic means one type of movement that is done repeatedly as well as movement speed running or another body $\operatorname{part}^{2}$. Speed is needed in athletes sprint runners(sprinter) required to run as fast as possible at the specified distance without any rhythm or cadence regulation in step to regulate breathing ${ }^{3}$. This sport is called sprint as the sport relies on the speed of the muscles, especially the leg muscles to be able to work at full power or full speed ${ }^{4}$.

Speed is determined by several factors: physiological and anatomical factors. Physiological factors that affect the speed of running that leg muscle strength, explosive power leg muscle, leg muscle flexibility. Anatomical factors (anthropometric) includes measurement of height, weight, and biotipolog 5 . Anthropometric indicators of differences in body structure can be measured by measuring Weight (BB), Height (TB), ratio Weight (BB) / Height (TB), Upper Arm Circumference (MUAC), and body mass index (BMI).

$\mathrm{BMI}$ is a relevant indicator to distinguish the capacity and performance of athletes. BMI is usually used to control the public health, but also a BMI measurement of relevant indicators to guide the individual in choosing a sport that will be occupied ${ }^{6}$. BMI measurement is one method that is simple, easy, and inexpensive yet for categorizing specific anthropometric structures of the body. Mass, height, and BMI is a major factor in influencing the speed ${ }^{6}$. This allows for the identification of physical optimally match the track and field events. BMI and the mass is a better indicator than height. However, BMI is preferred because it allows for a combined contribution of both.

Sprinter has more muscle and bone mass as they need stomping so hard to achieve maximum speed. BMI can guide some athletes toward body sizes that will optimize their performance ${ }^{7}$. Leg muscle is a muscle that is most responsible for sprinting (sprint) so that the increase in leg muscle strength will be a positive influence on the running speed. However, excessive weight is certainly not advisable for sprinter $^{8}$.

To make athletes excellent in the sport of sprint, BMI is expected to be one of the indicators that are useful in the categorization of athletes to the sport of running will be occupied. BMI is expected to become an important factor in influencing the running speed. Not a lot of data that reveal the relationship between BMI in influencing the running speed. Though the data is needed to optimize the performance of athletes sport sprint. 


\section{Methods}

This study is observational analytic research with cross-sectional study design. Measurement of independent variables and the dependent variable is done at the same time. This research was conducted in Sriwijaya Sport High School in Palembang. The sample selection using sampling techniques or total sampling, the sampling technique when all units of the population used as a sample unit.

This study uses primary data captured by using anthropometric measurements (stature meters, weight scales, meters) and assessment tests running speed of 50 meters. Athletes were instructed to run as far as 50 meters then measured his speed using a stopwatch. All measurement data collected are then entered into SPSS version 23

\section{Results}

\section{Characteristic of the subjects}

Table 1. Baseline Characteristics

\begin{tabular}{cccc}
\hline \multicolumn{2}{c}{ Characteristics } & n & \% \\
\hline Age & 16 & 5 & $14.3 \%$ \\
& 17 & 27 & $77.1 \%$ \\
& 18 & 3 & $8.6 \%$ \\
\hline Gender & Male & 19 & 54.3 \\
& Female & 16 & 45.7 \\
\hline Branch & Athletics & 9 & 25.7 \\
& Non- & 26 & 74.3 \\
& Athletics & & \\
\hline & Total & $\mathbf{3 5}$ & $\mathbf{1 0 0 \%}$ \\
\hline
\end{tabular}

\section{Anthropometric characteristics}

The weight of 35 research subjects is in the range of 46-74 kg with an average weight of $60 \mathrm{~kg}$. Height subjects in this study were within the range of 150.0 to $183.8 \mathrm{~cm}$ with an average height of $167 \mathrm{~cm}$. Distribution BMI research subjects had a mean BMI of 21,48 with the lowest 17.05 and the highest BMI was 27.12. Distribution of limb length of the subject on the measurement results shortest leg is the longest leg $88 \mathrm{~cm}$ and $109 \mathrm{~cm}$ is the average leg length is 97.44 $\mathrm{cm}$. Data subject anthropometric characteristics presented in tabular form in Table 2. 
Table 2. Distribution of Anthropometric Characteristics of data subjects

\begin{tabular}{ccccc}
\hline variable & $\mathbf{N}$ & Max & Min & mean \\
\hline Weight & 35 & 46.00 & 74.00 & 60.14 \\
Height & 35 & 150.00 & 183.80 & 166.93 \\
long & 35 & 88.00 & 109.00 & 97.37 \\
Limbs & & & & \\
BMI & 35 & $17: 06$ & 27.12 & $21: 56$ \\
\hline
\end{tabular}

\section{Running speed}

Table 3 shows the distribution of the running speed of the subject, with the average speed is $6.78 \mathrm{~m} / \mathrm{s}$. The minimum running speed research on the subject that is $5.67 \mathrm{~m} / \mathrm{s}$ and a maximum of $8.17 \mathrm{~m} / \mathrm{s}$. From 35 subjects, as many as 18 people $(51.4 \%)$ experienced fatigue and as many as 17 people (48.6\%) did not experience fatigue. Fatigue is meant here is condition entities subject being exhausted before performing the test speed to run a distance of 50 meters obtained from the anamnesis.

Table 3. Distribution of the running speed of data subjects $(N=35)$

\begin{tabular}{ccccc}
\hline variable & N & Min & Max & mean \\
\hline $\begin{array}{c}\text { Free } \\
\text { Running }\end{array}$ & 35 & 5.68 & $8: 17$ & 6.78 \\
\hline
\end{tabular}

\section{The relationship between Body Mass Index and running speed}

Pearson correlation values for BMI and Running Speed of $r=-0160$. The correlation between BMI and the running speed is weak. P-value 0359> $\hat{\mathrm{I}} \pm(0: 05)$ receive $\mathrm{H}_{0}$ so insignificant or no correlation. The graph in Figure 1 illustrates the distribution of running speed based on BMI. If the data points more in a straight line or linear, then the correlation is getting stronger. Based on the graph, it can be seen that the data points spread randomly does not follow a straight line it means the correlation between running speed and BMI weak. 


\section{ISSN 25980580}

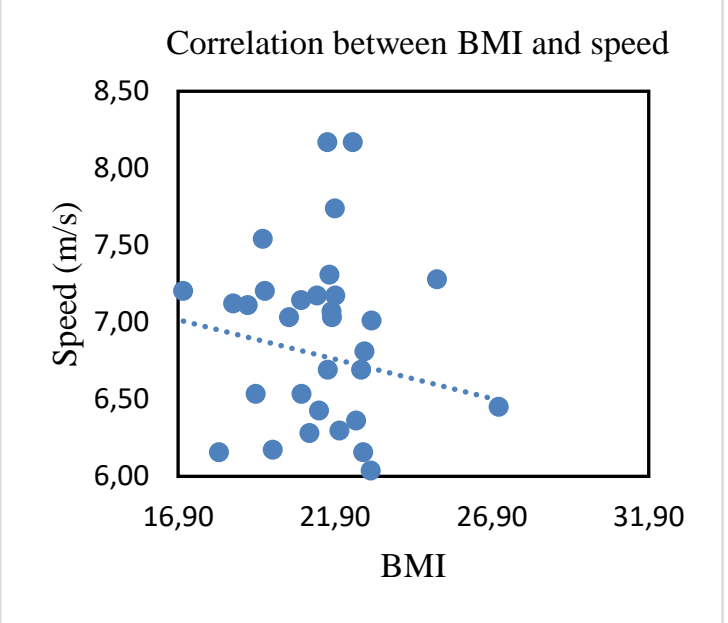

Figure 1. Scatter Plot Distribution graph running speed based on BMI (N = 35) confounding variables

In addition the relationship between running speed as the dependent variable and BMI as independent variables, bivariate analysis was also performed on confounding variables or other support to determine the distribution of the dependent variable in accordance with the variables supporters.

\section{The relationship between gender and running speed}

Levene's test (test of homogeneity of variance) get a p-value $0990>\alpha(0,05)$ so received $\mathrm{H}_{0}$ so that it can be stated that the variety of both groups. Then, P-value for unpaired t-test was $0.000<\alpha(0: 05)$ so reject H0. It can be concluded that with a confidence level of $95 \%$ is sufficient evidence to suggest that sex differences give a different effect on the running speed.

Judging from the average running speed, the male has a running speed higher than for women or in other words, men have the ability to run faster than women.

\section{The relationship between fatigue and Free Running}

Spearman correlation values for Fatigue and Free Running is for $r=-0272$. This value is still small and it can be stated that the closeness of the relationship between fatigue with Running speed is still weak. P-value 0.114> $\hat{\mathrm{I}} \pm(0: 05)$ Reject $\mathrm{H}_{0}$ so insignificant or no correlation.

\section{The relationship between the length of limbs and Free Running}

Pearson correlation value for Long Legs and Running Speed of $r=0.278$. This value is still small and it can be stated that the closeness of the relationship between the length of limbs 


\section{ISSN 25980580}

with Running speed is still weak. P-value 0.106> $\hat{\mathrm{I}} \pm(0: 05)$ receive $\mathrm{H}_{0}$ so insignificant or no correlation.

The graph in Figure 2 shows the distribution of the running speed based on the length of the leg. If the data points more in a straight line or linear, then the correlation is getting stronger. Based on the graph, it can be seen that the data points spread randomly does not follow a straight line it means the correlation between running speed and long legs are very weak.

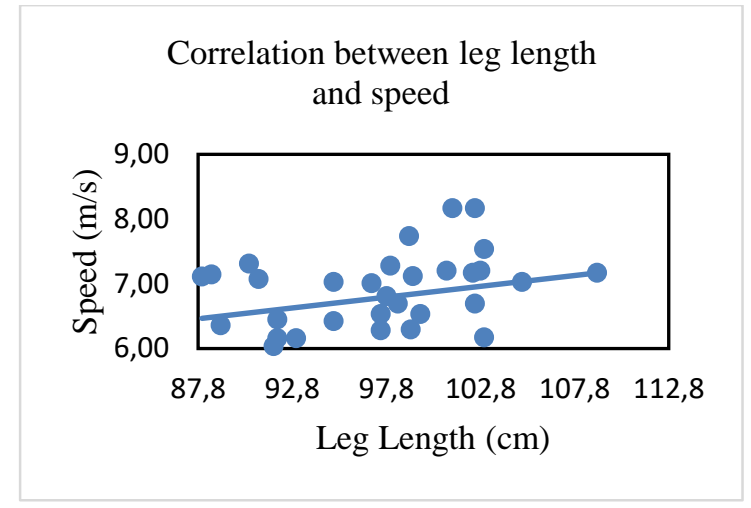

Figure 2. Scatter Plot Chart escape velocity distribution is based on the long leg $(\mathrm{N}=35)$

\section{Discussion}

Body Mass Index (BMI) is a calculation of the value taken from between weight and height of a person. The formula to calculate BMI is, BMI = Weight $(\mathrm{kg}) /[$ height $(\mathrm{m})]$. Normal BMI of 18.5 to 22.9. Results of research Arga (2008) showed that the degree of obesity had a great influence on the performance of the four components of fitness and ability tests ${ }^{9}$. Obesity is associated with reduced performance of athletes in tests of speed (velocity), endurance (durability), balance (balance) agility (agility) and power (explosive).

The degree of obesity has a major influence on the performance of the four components of fitness and athletic ability tests. Obesity is associated with reduced body athlete's performance on the tests speed (velocity), endurance (durability), balance (balance), agility (agility) and power (explosive). In this study, a BMI of all the athletes is in the range of 17.05 to 27.12 with an average BMI of 21,48 .

The results of the study in SMA Negeri Sriwijaya Palembang Sport concluded that there was no significant correlation between BMI and the running speed of high school students Sports Negeri Sriwijaya Palembang score $(r=-0.160)$, means that the correlation is still relatively low. A negative correlation means that the greater the BMI of a person then the less time it takes to run at a distance of 50 meters, in other words, the better the performance of athletes

The results of this analysis are not in accordance with the results of research Sedaud, A (2014) that there is a positive significant correlation between BMI and the running speed $(\mathrm{r}=$ $0.71)^{6}$. The results are consistent with the results of research Utari, A (2007) that there is a 
weak negative correlation between body mass index with the escape velocity in girls $(\mathrm{r}=-$ $0.495)^{10}$.

The results of this study are also consistent with the results of research Nuhmani, S (2014) in his research entitled "anthropometry and Functional Performance of Indian Elite Junior Tennis Players" that there is no significant correlation between BMI and the running speed $(\mathrm{r}=$ $0.038)^{11}$. The results are consistent with the theory put forward Pradana (2010), namely an increase in leg muscle strength will be a positive influence on the running speed but excessive weight is certainly not advisable for Sprinter ${ }^{8}$.

From the results of the study in SMA Negeri, Sriwijaya Palembang Sport concluded that there was no significant correlation between body mass index and speed to run at high school students of Sriwijaya Palembang Sport. The analysis showed that there is no significant correlation between limb length and speed to run at high school students Sports Negeri Sriwijaya Palembang, with values $(r=-0.263)$, means that the correlation is still relatively low. A negative correlation means that the person's leg length then the less time it takes to run at a distance of 50 meters, in other words, the better the performance of athletes.

There was a significant relationship between limb length and running speed with the ability to long jump squat style male student grade IV and V SD Negeri 1 Panunggalan Pengadegan Purbalingga the school year 2012/2013 to $r=0.809(12)$. In a study states that there is a correlation enough positive value between limb length with the running speed of 60 meters $(\mathrm{r}=0.411)^{13}$. There was a significant relationship between limb length with fast running speed 60 meters with a significance level of $5 \%$. While the value of $\mathrm{r}$ correlation of 0.923 , which means that the correlation or relationship between limb length with the achievement of sprinting 60 meters is a powerful ${ }^{14}$.

\section{The relationship between Gender and Free Running}

Levene's test (test of homogeneity of variance) get a p-value $0327>\alpha(0: 05)$ so thank $\mathrm{H} 0$ so that it can be stated that the variety of both groups. Then, P-value for unpaired t-test was $0.000<\alpha(0: 05)$ so reject $\mathrm{H}_{0}$. It can be concluded that with a confidence level of $95 \%$ is sufficient evidence to suggest that sex differences give a different effect on the running speed.

Judging from the value of the average travel time, the men have a travel time of less than women, or in other words, men have the ability to run faster than women.

The muscle strength tad bit stronger than the muscle strength of women at the age of 1012 years. Significant power difference occurs with age, in which the muscle strength of men much more powerful than women ${ }^{15}$. The influence of testosterone stimulate bone and muscle growth in men, plus differences in physical growth and physical activity also lead to women who lack the muscle strength of women is not as good as men. Even at the age of 18 years and above, the upper body muscle strength in men than women doubled, while the muscle strength of the lower body is different ${ }^{16}$.

Speed is determined by several factors: physiological and anatomical factors. Physiological factors that affect the speed of running that leg muscle strength, explosive power leg muscle, leg muscle flexibility ${ }^{17}$. Anatomical factors (anthropometric) includes 
measurement of height, weight, biotypology, and others-lain ${ }^{18}$. This study incorporates anatomical factors that affect the speed to run as an independent variable, namely BMI, long legs, physiological factors such as fatigue, and other factors, namely gender as a confounding variable.

The results of this study showed no significant correlation between body mass index and speed because there are other anthropometric factors such as biotypology as well as other factors that influence the results of assessment tests running speed of 50 meters. The research subject has given a prior explanation of the purpose and procedures of the study. However, internal factors such as genetics, age, and motivation to be a confounding variable that affects the speed test results in this study ${ }^{19}$.

\section{Conclusion}

There is a weak negative correlation between BMI and the running speed $(\mathrm{r}=-0.160)$. There is a weak positive correlation between fatigue and the running speed $(r=-0.272)$ and limb length and running speed $(\mathrm{r}=-0.263)$.

\section{References}

1. Purnomo E. Pedoman Mengajar Dasar Gerak Atletik. Yogyakarta Univ Negeri Yogyakarta. 2007;

2. Harsono MS, Drs MS. Coaching dan Aspek-aspek Psikologis dalam Coaching. Direktorat Jendral Pendidik Tinggi Jakarta. 1988;

3. Ferdian AWB. Hubungan antara panjang tungkai dan kekuatan otot tungkai dengan kemampuan lompat jauh gaya jongkok pada siswa putra kelas XI SMA Negeri 1

4. Zaldy F. Pengembangan isntrumen penilaian permainan sepakbola dalam pembelajaran pendidikan jasmani, olahraga dan kesehatan pada peserta didik sekolah dasar di KEcamatan Ilir Riau Kabupaten Sppeng. Pascasarjana 2013

5. Marsan RA. Kontribusi VO2 Max, power tungkai dan koordinasi mata tangan terhadap keterampilan bermain bola voli pada atlet Kabupaten Bulukumba. J Penjaskesrek STKIP Mega Rezky Makassar. 2017;3(1):40-52.

6. Sedeaud A, Marc A, Marck A, Dor F, Schipman J, Dorsey M, et al. BMI, a performance parameter for speed improvement. PLoS One. Public Library of Science; 2014;9(2):e90183.

7. Chelly SM, Denis C. Leg power and hopping stiffness: relationship with sprint running performance. Med Sci Sport Exerc. LWW; 2001;33(2):326-33.

8. Pradana A, Seno K, Puruhita N. Hubungan antara Indeks Massa Tubuh (IMT) dengan 
Nilai Lemak Viseral (Studi Kasus pada Mahasiswa Kedokteran Undip). Faculty of Medicine Diponegoro University; 2014.

9. Arga K. Pengaruh Plyometric Exercise Terhadap Peningkatan Daya Ledak Otot Lower Extremity. UPN Veteran Jakarta. 2008;

10. Utari A. Hubungan indeks massa tubuh dengan tingkat kesegaran jasmani pada anak usia 12-14 tahun. program Pascasarjana Universitas Diponegoro; 2007.

11. Nuhmani S, Akthar N. Anthropometry and functional performance of elite indian junior tennis players. J Sci. 2014;4(1):55-9.

12. Sorongan $\mathrm{CH}$. Hubungan Panjang Tungkai dengan Kecepatan Berjalan pada Siswa Sekolah Menengah Atas Negeri 6 Manado. J e-Biomedik. 2014;2(1).

13. Devi Puspitasari D. Hubungan panjang tungkai dan daya ledak otot tungkai dengan hasik lompat jauh gaya jongkok pada ekstrakurikuler SMPN 2 Kedu Temanggung tahun 2015. Universitas Wahid Hasyim; 2016.

14. Hanafi S. Efektifitas Latihan Beban Dan Latihan Pliometrik Dalam Meningkatkan Kekuatan Otot Tungkai Dan Kecepatan Reaksi. J Il. 2010;1(2):1-9.

15. Kamen G, Roy A. Motor unit synchronization in young and elderly adults. Eur J Appl Physiol. Springer; 2000;81(5):403-10.

16. Lloyd RS, Cronin JB, Faigenbaum AD, Haff GG, Howard R, Kraemer WJ, et al. National Strength and Conditioning Association position statement on long-term athletic development. J Strength Cond Res. Wolters Kluwer; 2016;30(6):1491-509.

17. Nala N. Prinsip pelatihan fisik olahraga. Denpasar Univ Udayana. 1998;

18. Winarni A. Pengaruh Latihan Rope Jump Dengan Metode Interval Training Terhadap Daya Tahan Otot Tungkai. J Kesehat Olahraga. 2015;3(1).

19. Septadina IS, Irfannudin S. I., dan Mujahidin. 2016. Hubungan antara Tipe Tubuh dengan Kelincahan dan Kecepatan Gerak pada Anak Usia 10-12 Tahun. In: Forum Penelitian. p. 1. 